\title{
Immune priming against bacteria in spiders and scorpions?
}

\author{
Dumas Galvez ${ }^{\text {Corresp., } 1,2}{ }^{,}$Yostin Añino ${ }^{3}$, Carlos Vega $^{4}$, Eleodoro Bonilla ${ }^{4}$ \\ 1 Programa Centroamericano de Maestría en Entomología, Universidad de Panamá, Panama, Panama \\ 2 COIBA AIP, Panama, Panama \\ 3 Museo de Invertebrados G.B. Fairchild, Universidad de Panamá, Panama, Panama \\ 4 Escuela de Biología, Universidad de Panamá, Panama, Panama \\ Corresponding Author: Dumas Galvez \\ Email address: dumas.galvezs@up.ac.pa
}

Empirical evidence of immune priming in arthropods keeps growing, both at the withinand trans-generational level. The evidence comes mostly from work on insects and it remains unclear for some other arthropods whether exposure to a non-lethal dose of a pathogen provides protection during a second exposure with a lethal dose. A poorly investigated group are arachnids, with regard to the benefits of immune priming measured as improved survival. Here, we investigated immune priming in two arachnids: the wolf spider Lycosa cerrofloresiana and the scorpion Centruroides granosus. We injected a third of the individuals with lipopolysaccharides of Escherichia coli (LPS, an immune elicitor), another third were injected with the control solution (PBS) and the other third were kept naive. Four days after the first inoculations, we challenged half of the individuals of each group with an injection of a high dose of $E$. coli and the other half was treated with the control solution. For scorpions, individuals that were initially injected with PBS or LPS did not differ in their survival rates against the bacterial challenge. Individuals injected with LPS showed higher survival than that of naive individuals as evidence of immune priming. Individuals injected with PBS tended to show higher survival rates than naive individuals, but the difference was not significant - perhaps suggesting a general immune upregulation caused by the wounding done by the needle. For spiders, we did not observe evidence of priming, the bacterial challenge reduced the survival of naive, PBS and LPS individuals at similar rates. Moreover; for scorpions, we performed antibacterial assays of hemolymph samples from the three priming treatments (LPS, PBS and naive) and found that the three treatments reduced bacterial growth but without differences among treatments. As non-model organisms, with some unique differences in their immunological mechanisms as compared to the most studied arthropods (insects), arachnids provide an unexplored field to elucidate the evolution of immune systems. 


\section{Immune priming against bacteria in spiders and}

\section{2 scorpions?}

3 Dumas Gálvez ${ }^{1,2}$, Yostin Añino ${ }^{3}$, Carlos Vega ${ }^{4} \&$ Eleodoro Bonilla ${ }^{4}$

$4 \quad{ }^{1}$ PCMENT, Universidad de Panamá,

$5 \quad 2$ COIBA AIP, Panama, Panama

$6 \quad{ }^{3}$ Museo de Invertebrados G.B. Fairchild, Universidad de Panamá, Panama, Panama.

$7 \quad{ }^{4}$ Escuela de Biología, Universidad de Panamá, Panama, Panama.

8 Corresponding Author:

9 Dumas Gálvez ${ }^{1}$

10 Avenida Simón Bolívar, Panama, Panama, 0824, Panama

11 Email address: dumas.galvezs@up.ac.pa

12 Abstract

13 Empirical evidence of immune priming in arthropods keeps growing, both at the within- and

14 trans-generational level. The evidence comes mostly from work on insects and it remains unclear

15 for some other arthropods whether exposure to a non-lethal dose of a pathogen provides

16 protection during a second exposure with a lethal dose. A poorly investigated group are

17 arachnids, with regard to the benefits of immune priming measured as improved survival. Here,

18 we investigated immune priming in two arachnids: the wolf spider Lycosa cerrofloresiana and

19 the scorpion Centruroides granosus. We injected a third of the individuals with

20 lipopolysaccharides of Escherichia coli (LPS, an immune elicitor), another third were injected

21 with the control solution (PBS) and the other third were kept naive. Four days after the first

22 inoculations, we challenged half of the individuals of each group with an injection of a high dose 
23 of E. coli and the other half was treated with the control solution. For scorpions, individuals that

24 were initially injected with PBS or LPS did not differ in their survival rates against the bacterial

25 challenge. Individuals injected with LPS showed higher survival than that of naive individuals as

26 evidence of immune priming. Individuals injected with PBS tended to show higher survival rates

27 than naive individuals, but the difference was not significant — perhaps suggesting a general

28 immune upregulation caused by the wounding done by the needle. For spiders, we did not

29 observe evidence of priming, the bacterial challenge reduced the survival of naive, PBS and LPS

30 individuals at similar rates. Moreover; for scorpions, we performed antibacterial assays of

31 hemolymph samples from the three priming treatments (LPS, PBS and naive) and found that the

32 three treatments reduced bacterial growth but without differences among treatments. As non-

33 model organisms, with some unique differences in their immunological mechanisms as

34 compared to the most studied arthropods (insects), arachnids provide an unexplored field to

35 elucidate the evolution of immune systems.

\section{Introduction}

38 The invertebrate immune system was traditionally believed to contain no memory and 39 specificity. This is due to the lack of immune machinery that is needed in order to develop the

40 desired immune response in vertebrates (Rowley \& Powell, 2007). However, recent literature has 41 reported that invertebrates exposed to a low dose of a pathogen can obtain protection against a 42 subsequent lethal dose of the same pathogen, a phenomenon termed as immune priming (Little \& 43 Kraaijeveld, 2004). This improved immune response can be observed within a few days after the 44 priming, in later stages of the individual ('within-generation immune priming', Milutinović \& 
45 Kurtz, 2016) or even transferred to the offspring ('trans-generational immune priming', Tetreau 46 et al., 2019).

47 Evidence of immune priming comes mostly from insects (Milutinović et al., 2016; Cooper \& 48 Eleftherianos, 2017). However, a number of studies found no evidence of immune priming in 49 insects against fungi (Reber \& Chapuisat, 2012; Gálvez \& Chapuisat, 2014), bacteria (González-

50 Tokman et al., 2010; Patrnogic et al., 2018) and bacterial immune elicitors (ter Braak et al., 51 2013; Wu et al., 2015b). In some cases the detection depended on the pathogen used (Pham et 52 al., 2007; Vargas et al., 2016; Ferro et al., 2019). Overall, the detection of immune priming in 53 insects seems to depend on multiple factors such as host - pathogen combination, host lifespan, 54 priming method, pathogen dose, virulence, among others (Contreras-Garduño, 2016; Milutinović 55 et al., 2016; Cooper \& Eleftherianos, 2017; Tetreau et al., 2019).

56 Even though it is thought that the immune system of arthropods is well conserved across species,

57 based on an innate immune system, consisting of cellular and humoral responses (Rowley \& 58 Powell, 2007), recent studies showed there exists some variation across taxa and the insect 59 immune system that which does not necessarily characterize other arthropods. For instance, 60 Bechsgaard et al. (2016) discovered that some genes involved in pathways for pathogen 61 recognition (e.g. bacteria) have been lost in arachnids and the humoral immune effector proteins 62 (antimicrobial peptides, AMPs) are apparently not induced as it is the case for insects, but they 63 are constitutively produced, a trend also observed by previous studies (Lorenzini et al., 2003;

64 Fukuzawa et al., 2008; Baumann et al., 2010; González-Tokman et al., 2014). In other arachnids, 65 the evidence seems to suggest a complete absence of an induced immune response (Santos66 Matos et al., 2017). Another example of dissimilarities between insects and arachnids is the 67 evidence indicating that phagocytosis plays a role in the immune priming of insects (Pham et al., 
68 2007; Wu et al., 2015a). However, in spiders, phagocytosis seems to play a minor role in defense

69 when compared to AMPs and coagulation (Fukuzawa et al., 2008). Overall, whether these

70 differences in arachnids' immune systems influence their capacity to mount an immune priming

71 response is unclear.

72 Immunological studies and evidence of immune priming in arachnids come mainly from work

73 with ticks, given their medical importance, with evidence of upregulation (Nakajima et al., 2001;

74 Matsuo et al., 2004) and improved survival after exposure to an immune elicitor, controlled by

75 molecular pathways that are apparently unique to ticks (Shaw et al., 2017). Moreover, blood-

76 feeding can strongly upregulate defensin genes in the midgut, which normally occurs in the fat

77 body after bacterial infection in insects [review in Taylor, 2006]. Ticks as hematophagous are an

78 atypical group of arachnids in terms of the use of immune defenses; for instance, ticks can use

79 fragments of the host blood for their own defense against bacteria in the midgut level (Nakajima

80 et al., 2003, 2005), together with their own antibacterial peptides (Nakajima et al., 2005) or with

81 the influence of commensal and symbiont bacteria (Chávez et al., 2017). In contrast, knowledge

82 about the immune system of other arachnids remains mostly unknown.

83 In fact, no experimental study has investigated immune priming in terms of increased survival in

84 non-hematophagous arachnids like spiders or scorpions (Milutinović \& Kurtz, 2016; Milutinović

85 et al., 2016). By studying the immune response of other arachnids, analogies and differences

86 with other taxa can be established in order to understand the evolution of the immune systems in

87 invertebrates. Here, we performed the first test of immune priming in spiders and scorpions in

88 terms of improved survival. We investigated whether the wolf spider Lycosa cerrofloresiana

89 (Lycosidae) and the scorpion Centruroides granosus (Buthidae) can mount an immune priming

90 response when injected with lipopolysaccharides (LPS) of Escherichia coli and subsequently 
91 challenged with a lethal dose of the same bacteria. If antimicrobial peptides are constitutively

92 produced, then their immune system may always be prepared for an immune challenge and

93 exposure to a priming agent may not be required. Alternatively, priming would both trigger the

94 release of constitutive components and induce recruitment of production of higher levels of

95 antimicrobials components.

\section{Materials \& Methods}

98 Study species

99 This study was carried out with two nocturnal terrestrial predators, the wolf spider Lycosa 100 cerrofloresiana Petrunkevitch, 1925 and the scorpion Centruroides granosus Thorell, 1876

101 (Buthidae). Lycosa cerrofloresiana is found from El Salvador to Panama (World Spider Catalog, 102 2019), while C. granosus is endemic to Panama (de Armas, Teruel \& Kovařík, 2011). For both 103 species, all the existing literature is on aspects of taxonomy and distribution (e.g. de Armas, 104 Teruel \& Kovařík, 2011; World Spider Catalog, 2019 and references therein). Still, Centruroides 105 granosus prey on a variety of arthropods, including insects and other arachnids (Miranda et al., 106 2015). Literature on the diet of the wolf spider is missing but we have noticed spiders eating 107 crickets and cockroaches in the field.

108 Spiders were collected from a baseball field in the town of Gamboa $\left(09^{\circ} 07^{\prime} 05.1596^{\prime \prime},-\right.$ 109 079 42'03.5266") and scorpions were collected from a dirt road in the town of Polanco 110 (0845'44.3196", -07948'22.8618"). All individuals were fed with the cricket Acheta

111 domesticus, one week before the experiments. The study did not involve unethical handling of 112 animals and did not require permits for experimentation by the Bioethics Office from the 113 University of Panama. We collected all specimens under the collection permit SE/AH-2-18 
114 issued by the 'Ministerio de Ambiente', the government entity in charge of the management of 115 natural resources.

116 Immune priming

117 A strain of Escherichia coli was used for the experiments, which was obtained through isolation 118 with selective media by the Department of Microbiology of the Biology School at the University 119 of Panama. Tests of virulence of this strain produced high mortality in both spiders and scorpions 120 (Supplementary material). Previous studies have used E. coli via injection or pricking as an 121 immune elicitor in other arthropods (Eleftherianos et al., 2006; Roth \& Kurtz, 2009; Erler, Popp

122 \& Lattorff, 2011; Santos-Matos et al., 2017) and arachnids (Sonenshine et al., 2003; Santos123 Matos et al., 2017).

124 We used chilling anesthesia for all injections, which consisted of placing scorpions and spiders at $1254{ }^{\circ} \mathrm{C}$ for 20 minutes. In order to stimulate priming, we injected spiders with $138 \mathrm{~nL}$ of LPS in 126 PBS (0.5 mg / mL; Sigma: L8274; hereafter LPS) by using a Nanoliter 2010 injector (WPI, 127 Florida, USA). For scorpions, we picked $100 \mu \mathrm{L}$ of the LPS solution with a micropipette to fill 128 insulin syringes used for the injections. Control groups consisted of individuals injected only 129 with PBS and another group of untreated individuals (naive) to test whether the mechanical 130 damage caused by the injections was enough to prime the immune system. For spiders, the 131 injection procedure during the priming caused around $1 \%$ mortality and there was no mortality in 132 scorpions.

133 For the bacterial challenge, bacteria were cultured overnight on lysogeny broth (LB) at $27^{\circ} \mathrm{C}$. We 134 centrifuged $14 \mathrm{ml}$ of the culture $\left(\mathrm{LD}_{50} 1 \times 10^{7}\right.$ cells $\left./ \mathrm{mL}\right)$ at $4000 \mathrm{rpm}$ for 5 minutes, the pellet 135 was washed with PBS and resuspended in $14 \mathrm{ml}$ of PBS. Four days after the initial injections, 136 half of the individuals in each treatment were injected with the bacterial solution $(138 \mathrm{~nL}$ for 
137 spiders and $100 \mu \mathrm{L}$ for scorpions; Naive - Challenged, PBS - Challenged, LPS - Challenged,

138 see Figure 1 for details on sample sizes). As controls, the other half of the individuals of each

139 treatment were injected only with PBS (138 nL for spiders and $100 \mu \mathrm{L}$ for scorpions; Naive -

140 Control, PBS - Control, LPS - Control, see Figure 1 for details on sample sizes). We performed

141 the experiments twice, on separate dates and monitored the survival of spiders and scorpions for

14215 days after the final challenge.

143 Antibacterial activity

144 For these measurements, we were only able to collect sufficient hemolymph samples from

145 individual scorpions. To test whether the priming with LPS upregulated the production of

146 antimicrobial components found in the hemolymph, we measured antibacterial activity following

147 a protocol modified from $\mathrm{Wu}$ et al (Wu et al., 2014). Three days after the priming phase, we

148 collected $10 \mu \mathrm{L}$ of hemolymph from each treatment (Naive: $\mathrm{n}=9$; PBS: $\mathrm{n}=6$ and LPS: $\mathrm{n}=9$ ) by

149 pricking chilled animals and placed it immediately in ice and later stored at $-20{ }^{\circ} \mathrm{C}$. The

150 antibacterial test consisted of mixing $10 \mu \mathrm{L}$ of cell-free hemolymph (centrifuged at $4000 \mathrm{rpm}$ for

1515 minutes $)$ with $10 \mu \mathrm{L}$ of $E$. coli culture $\left(1 \times 10^{7}\right.$ cells $\left./ \mathrm{mL}\right)$ in $180 \mu \mathrm{L}$ of LB and incubated

152 during 14 hours at $27^{\circ} \mathrm{C}$ in $1.5 \mathrm{~mL}$ Eppendorf tubes.

153 Antibacterial activity was quantified as inhibition of bacterial growth in the samples by

154 measuring optical density at $630 \mathrm{~nm}$ on a 96-well microplate reader. To evaluate whether the

155 hemolymph samples inhibited the bacterial growth, we used a positive control in which we

156 placed $10 \mu \mathrm{L}$ of $E$. coli culture in $190 \mu \mathrm{L}$ of $\mathrm{LB}$ (three replicates).

157 Statistical Analysis

158 All analyses were performed in R (R Development Core Team, 2019). The Kaplan-Meier

159 survival analysis was carried out to test for differences in survival rates between treatments as 
160 implemented in the package 'survival'. Moreover, we tested for differences between sexes in

161 both species as a fixed factor. We used the Gehan-Breslow-Wilcoxon test to compare survival

162 rates across treatments at early time points and the log-rank test to compare treatments at the end

163 of the experiments (package survMisc). For the antibacterial activity, we performed a one-

164 sample Wilcoxon test for each treatment to assess whether the priming treatment reduced

165 bacterial growth as compared to the mean bacterial growth in the absence of hemolymph $\left(\mathrm{OD}_{630}\right.$ $166=0.763$ ). To compare treatments, we carried out a Kruskal-Wallis test.

\section{Results}

Immune priming

169 For scorpions, overall, sex has no effect on survival (log-rank: $\mathrm{z}=-0.04, \mathrm{p}=0.97)$. The bacterial 170 challenge significantly reduced the survival in each treatment (Naive - Bacteria vs Naive - PBS,

171 PBS - Bacteria vs PBS - PBS, LPS - Bacteria vs LPS - PBS, Fig. 1A, Table 1). We found

172 evidence of immune priming because scorpions initially injected with LPS showed higher levels 173 of survival against the bacterial challenge than that of naive scorpions (LPS - Bacteria vs Naive -

174 Bacteria, Fig. 1A, Table 1). Although the results suggests that the priming could be elicited by 175 the wounding caused by the injection, this trend was not significant overall (PBS - Bacteria vs

176 Naive - Bacteria, Table 1) and neither during the early stages of the infection (Gehan-Breslow-

177 Wilcoxon test in Table 1).

178 The survival between scorpions injected initially with PBS or LPS against the bacterial challenge 179 was not significantly different (PBS - Bacteria vs LPS - Bacteria, Fig. 1A, Table 1). The survival 180 of controls of the three treatments were not significantly different (Naive - PBS vs PBS - PBS, 181 Naive - PBS vs LPS - PBS, PBS - PBS vs LPS - PBS, Fig. 1A, Table 1). 
182 For spiders, the influence of sex on survival was investigated in the first trial and was not 183 significant $(\mathrm{z}=-1.89, \mathrm{p}=0.06)$. The bacterial challenge significantly reduced the survival of all 184 the priming treatments (Naive - Bacteria vs Naive - PBS, PBS - Bacteria vs PBS - PBS, LPS 185 Bacteria vs LPS - PBS, Fig. 1B, Table 1). The three priming treatments did not vary in the 186 survival against the bacterial challenge (Naive - Bacteria vs PBS - Bacteria, Naive - Bacteria vs 187 LPS - Bacteria, PBS - Bacteria vs LPS - Bacteria, Fig. 1B, Table 1). The controls of the three 188 priming treatments were not significantly different (Naive - PBS vs PBS - PBS, Naive - PBS vs LPS - PBS, PBS - PBS vs LPS - PBS, Fig. 1B, Table 1).

190

191

192 193 195 196

197 Discussion

\section{Antibacterial activity}

Hemolymph of naive scorpions inhibited E. coli growth when compared to the average growth of the bacteria without hemolymph (Wilcoxon: $V=0, p=0.002, n=9$, Fig. 2) as well as the hemolymph of scorpions injected with PBS (Wilcoxon: $V=2, p=0.05, n=6$, Fig. 2) and the hemolymph of scorpions injected with LPS (Wilcoxon: $V=6, p=0.03, n=9$, Fig. 2). Overall, there were no differences between priming treatments in their capacity to inhibit bacterial growth (Kruskal-Wallis: $\mathrm{X}^{2}=0.27$, d.f. $=2, \mathrm{p}=0.87$, Fig. 2).

198 Scorpions as organisms with relatively long lifespans (Lourenço, 2000) are more likely to be exposed to a pathogen multiple times during their lifetime; therefore, they are good candidates to show immune priming (Best et al., 2013). Indeed, we found evidence of immune priming in terms of improved survival for individuals that were treated with LPS as compared to naive

202 individuals. It is unclear whether wounding by itself is sufficient to elicit priming since control 203 individuals (injected with PBS) showed similar survival against the bacteria to individuals 204 injected with LPS or kept naive. Thus, further work should evaluate whether wounding may be 
205 sufficient to trigger priming in arachnids as seen in other arthropods (Korner \& Schmid-Hempel, 206 2004; Roth et al., 2010; Nam et al., 2012). Perhaps danger-associated molecular patterns

207 (DAMPs) associated to wound healing could trigger immune priming (Krautz, Arefin \&

208 Theopold, 2014) or they may allow the entrance of pathogens that trigger the priming.

209 The presence of LPS in the hemolymph should have triggered the production of AMPs

210 (Rodríguez De La Vega et al., 2004) or other antimicrobial effectors; however, our antibacterial 211 activity assay with scorpions' hemolymph suggests that there was no upregulation of AMPs in 212 primed individuals, in line with previous work in scorpions comparing control and challenged 213 individuals (Cocianich et al., 1993; Ehret-Sabatier et al., 1996). However, the freezing and 214 thawing of the samples may have influenced the antibacterial effect, as it was not a part of the 215 original protocol or perhaps the detection of an effect requires larger sample sizes. Another 216 concern is that the immunological history of the individuals used for experimentation was 217 unknown (e.g. priming occurring before the experiments) and whether this influences the 218 immune priming response. Future studies should try to establish potential model species that 219 could be reared in the laboratory for immunological studies.

220 The improved resistance by priming may result from other factors or in interaction with AMPs in 221 the hemolymph, which might not perform well in the medium used for our assay. Rodríguez De 222 La Vega et al. (2004) found in Centruroides limpidus the existence of inducible AMPs and 223 proposed a cooperative antibacterial activity with constitutive hemolymph components. Still, the 224 differences between the survival experiment and the antibacterial activity illustrate how disease 225 resistance and immunity assays may not correlate or are pathogen dependent (review in Adamo, 226 2004); consequently, providing different resolutions to the experimental detection of immune 227 priming in arthropods. Furthermore, assays developed for insects may not be appropriate for 
228 arachnids as pointed out by other studies (Gilbert, Karp \& Uetz, 2016). Future studies should

229 investigate the efficacy of different methods to measure immune components in arachnids.

230 In spiders, Gilbert, Karp \& Uetz (2016) provided some indirect evidence of immune priming,

231 finding in the wolf spider Schizocosa ocreata that juveniles fed with another gram-negative

232 pathogenic bacteria showed higher encapsulation response against a nylon monofilament implant

233 in the adult stage. In contrast, we did not find benefits in terms of increased survival for wolf

234 spiders that were 'primed' and challenged in the adult stage, suggesting that the age in which

235 priming occurs should be examined. Future studies on arachnids should be aimed at identifying

236 mechanisms, including multiple host - pathogen or host - elicitor (e.g. dead pathogen, other

237 molecules) combinations to evaluate specificity, duration, the effect of symbionts or other

238 potential influential factors. For example, the mode of infection: Keiser et al. (2016) showed that

239 a bacterial cocktail increased mortality of a social spider via cuticular topical application while

240 on the contrary spiders fed with crickets injected with the same bacterial cocktail showed longer

241 lifespans than spiders fed with control crickets.

242 Arachnids offer systems to study other means of defense against pathogens. For instance, the silk

243 of spiders can have antibacterial properties (Wright \& Goodacre, 2012) and cuticular antifungals

244 have been found in subsocial spiders (González-Tokman et al., 2014). In addition, there is

245 extensive evidence revealing AMPs in the venom of spiders and scorpions that are active against

246 bacteria, fungi, viruses and parasites in vitro, which is being aimed at medical applications

247 (Santos, Reis \& Pimenta, 2016; Wang \& Wang, 2016). However, we are not aware of studies

248 that investigated the venom - immune system interaction in arachnids when coping with

249 pathogens. Our priming procedure and lethal injection did not allow the interaction between the

250 venom and the bacteria. One might expect that the deactivation of the bacteria by the venom 
251 inoculated in the prey may generate a form of priming agent (e.g. dead bacteria) that would act

252 after ingestion.

253 Despite the inherent differences in the immune system of insects and spiders, immune priming

254 seems to be conserved as a general protection mechanism across arthropods taxa. As non-model

255 organisms, arachnids provide alternative systems to study the evolution of immune systems in

256 non-vertebrate animals and our study adds support to the hypothesis that all organisms should

257 have some sort of acquired immunity (Rimer, Cohen \& Friedman, 2014).

\section{Conclusions}

259 The aim of the study was to test whether immune priming occurred in two arachnid species: a

260 scorpion and a wolf spider. Injection of bacterial components (LPS) seemed to trigger the

261 immune system of the scorpions as they showed improved survival against alive bacteria as

262 compared to individuals that remained untreated (naive). However, scorpions injected with LPS

263 showed similar survival rates as scorpions injected with only a saline solution (PBS), suggesting

264 that the damage caused by injection may be enough to trigger the upregulation of the immune

265 system. The lack of differences in antibacterial assays with scorpions' hemolymph from the

266 different treatments; together with the lack of evidence for immune priming in spiders, it

267 indicates that the experimental detection of this phenomenon may depend on multiple variables

268 (host - pathogen, priming method, host lifespan, virulence, among other) as proposed in the

269 literature.

\section{Acknowledgements}

271 We thank Griselda Arteaga from the Faculty of Medicine at the University of Panama for

272 facilitating the use of the microplate reader. We also thank Alexandre Chausson for his 
273 comments on the manuscript; David Camacho, Randhy Rodríguez and Bastien König for their

274 help in the field and laboratory.

275

276

\section{References}

277

278

279

280

281

282

283

284

285

286

287

288

289

290

291

292

293

294

295

296

297

298

299

300

301

302

303

304

305

306

307

308

309

310

311

312

313

314

315

Adamo SA. 2004. How should behavioural ecologists interpret measurements of immunity? Animal Behaviour 68:1443-1449. DOI: 10.1016/j.anbehav.2004.05.005.

de Armas LF, Teruel R, Kovařík F. 2011. Redescription of Centruroides granosus (Thorell, 1876) and identity of Centrurus granosus simplex Thorell, 1876 (Scorpiones: Buthidae). Euscorpius 2011:1-11. DOI: 10.18590/euscorpius.2011.vol2011.iss 127.1.

Baumann T, Kuhn-Nentwig L, Largiadèr CR, Nentwig W. 2010. Expression of defensins in noninfected araneomorph spiders. Cellular and Molecular Life Sciences 67:2643-2651. DOI: 10.1007/s00018-010-0354-2.

Bechsgaard J, Vanthournout B, Funch P, Vestbo S, Gibbs RA, Richards S, Sanggaard KW, Enghild JJ, Bilde T. 2016. Comparative genomic study of arachnid immune systems indicates loss of $\beta$ GRPs and the IMD pathway. Journal of Evolutionary Biology 29:277291. DOI: $10.1111 /$ jeb.12780.

Best A, Tidbury H, White A, Boots M. 2013. The evolutionary dynamics of within-generation immune priming in invertebrate hosts. Journal of the Royal Society Interface 10:20120887. DOI: 10.1098/rsif.2012.0887.

ter Braak B, Laughton AM, Altincicek B, Parker BJ, Gerardo NM. 2013. Exposure to bacterial signals does not alter pea aphids' survival upon a second challenge or investment in production of winged offspring. PloS one 8:e73600. DOI: 10.1371/journal.pone.0073600.

Chávez ASO, Shaw DK, Munderloh UG, Pedra JHF. 2017. Tick humoral responses: marching to the beat of a different drummer. Frontiers in Microbiology 8:223. DOI: 10.3389/fmicb.2017.00223.

Cocianich S, Goyffon M, Bontems F, Bulet P, Bouet F, Menez A, Hoffmann J. 1993. Antimicrobial peptide induction in the haemolymph of the Mexican scorpion Centruroides limpidus limpidus in response to septic injury. Biochemical and Biophysical Research Communications 194:17-22. DOI: 10.1007/s00018-004-4096-X.

Contreras-Garduño J. 2016. Insect immune priming: ecology and experimental. Ecological Entomology 41:351-366. DOI: 10.1111/een.12300.

Cooper D, Eleftherianos I. 2017. Memory and Specificity in the Insect Immune System: Current Perspectives and Future Challenges. Frontiers in Immunology 8:539. DOI: 10.3389/fimmu.2017.00539.

Ehret-Sabatier L, Loew D, Goyffon M, Fehlbaum P, Hoffmann JA, Van Dorsselaer A, Bulet P. 1996. Characterization of novel cysteine-rich antimicrobial peptides from scorpion blood. Journal of Biological Chemistry 271:29537-29544. DOI: 10.1074/jbc.271.47.29537.

Eleftherianos I, Marokhazi J, Millichap PJ, Hodgkinson AJ, Sriboonlert A, Ffrench-Constant RH, Reynolds SE. 2006. Prior infection of Manduca sexta with non-pathogenic Escherichia coli elicits immunity to pathogenic Photorhabdus luminescens: roles of immune-related proteins shown by RNA interference. Insect Biochemistry and Molecular Biology 36:517525. DOI: 10.1016/j.ibmb.2006.04.001. 
316

317

318

319

320

321

322

323

324

325

326

327

328

329

330

331

332

333

334

335

336

337

338

339

340

341

342

343

344

345

346

347

348

349

350

351

352

353

354

355

356

357

358

359

360

361
Erler S, Popp M, Lattorff HMG. 2011. Dynamics of immune system gene expression upon bacterial challenge and wounding in a social insect (Bombus terrestris). PloS one 6:e18126. DOI: 10.1371/journal.pone.0018126.

Ferro K, Peuß R, Yang W, Rosenstiel P, Schulenburg H, Kurtz J. 2019. Experimental evolution of immunological specificity. Proceedings of the National Academy of Sciences 116:2059820604. DOI: 10.1073/pnas.1904828116.

Fukuzawa AH, Vellutini BC, Lorenzini DM, Silva PI, Mortara RA, da Silva JMC, Daffre S. 2008. The role of hemocytes in the immunity of the spider Acanthoscurria gomesiana. Developmental and Comparative Immunology 32:716-725. DOI: 10.1016/j.dci.2007.11.002.

Gálvez D, Chapuisat M. 2014. Immune priming and pathogen resistance in ant queens. Ecology and Evolution 4:1761-1767. DOI: 10.1002/ece3.1070.

Gilbert R, Karp RD, Uetz GW. 2016. Effects of juvenile infection on adult immunity and secondary sexual characters in a Wolf spider. Behavioral Ecology 27:946-954. DOI: 10.1093/beheco/arv241.

González-Tokman DM, González-Santoyo I, Lanz-Mendoza H, Córdoba Aguilar A. 2010. Territorial damselflies do not show immunological priming in the wild. Physiological Entomology 35:364-372. DOI: 10.1111/j.1365-3032.2010.00752.x.

González-Tokman D, Ruch J, Pulpitel T, Ponton F. 2014. Cuticular antifungals in spiders: Density- and condition dependence. PLoS ONE 9:e91785. DOI: 10.1371/journal.pone.0091785.

Keiser CN, Shearer TA, Demarco AE, Brittingham HA, Knutson KA, Kuo C, Zhao K, Pruitt JN. 2016. Cuticular bacteria appear detrimental to social spiders in mixed but not monoculture exposure. Current Zoology 62:377-384. DOI: 10.1093/cz/zow015.

Korner P, Schmid-Hempel P. 2004. In vivo dynamics of an immune response in the bumble bee Bombus terrestris. Journal of invertebrate Pathology 87:59-66. DOI: 10.1016/j.jip.2004.07.004.

Krautz R, Arefin B, Theopold U. 2014. Damage signals in the insect immune response. Frontiers in Plant Science 5:1-11. DOI: 10.3389/fpls.2014.00342.

Little TJ, Kraaijeveld AR. 2004. Ecological and evolutionary implications of immunological priming in invertebrates. Trends in Ecology \& Evolution 19:58-60.

Lorenzini DM, Da Silva PI, Fogaça AC, Bulet P, Daffre S. 2003. Acanthoscurrin: A novel glycine-rich antimicrobial peptide constitutively expressed in the hemocytes of the spider Acanthoscurria gomesiana. Developmental and Comparative Immunology 27:781-791. DOI: $10.1016 / \mathrm{S} 0145-305 X(03) 00058-2$.

Lourenço WR. 2000. Reproduction in scorpions, with special reference to parthenogenesis. In: Toft S, Scharff N eds. European Arachnology. Aarus: Aarhus University Press, 71-85.

Matsuo T, Okoda Y, Badgar B, Inoue N, Xuan X, Taylor DM, Fujisaki K. 2004. Fate of GFPexpressing Escherichia coli in the midgut and response to ingestion in a tick, Ornithodoros moubata (Acari: Argasidae). Experimental Parasitology 108:67-73. DOI: 10.1016/j.exppara.2004.07.014.

Milutinović B, Kurtz J. 2016. Immune memory in invertebrates. Seminars in Immunology 28:328-342. DOI: 10.1016/j.smim.2016.05.004.

Milutinović B, Peuß R, Ferroa K, Kurtz J. 2016. Immune priming in arthropods: an update focusing on the red flour beetle. Zoology 119:254-261. DOI: 10.1016/j.zool.2016.03.006.

Miranda R, Bermúdez S, Cleghorn J, Cambra RA. 2015. Presas de escorpiones (Arachnida: 
362

363

364

365

366

367

368

369

370

371

372

373

374

375

376

377

378

379

380

381

382

383

384

385

386

387

388

389

390

391

392

393

394

395

396

397

398

399

400

401

402

403

404

405

406

407
Scorpiones) de Panamá, con observaciones sobre el comportamiento de depredación. Revista Ibérica de Arachnología 27:115-123.

Nakajima Y, Van Naters-Yasui AVDG, Taylor D, Yamakawa M. 2001. Two isoforms of a member of the arthropod defensin family from the soft tick, Ornithodoros moubata (Acari: Argasidae). Insect Biochemistry and Molecular Biology 31:747-751.

Nakajima Y, Ogihara K, Taylor D, Yamakawa M. 2003. Antibacterial hemoglobin fragments from the midgut of the soft tick, Ornithodoros moubata (Acari: Argasidae). Journal of Medical Entomology 40:78-81.

Nakajima YN, Saido-Sakanaka H, Ogihara K, Taylor D, Yamakawa M. 2005. Antibacterial peptides are secreted into the midgut lumen to provide antibacterial midgut defense in the soft tick, Ornithodoros moubata (Acari: Argasidae ). Applied Entomology and Zoology 40:391-397. DOI: 10.1303/aez.2005.391.

Nam HJ, Jang IH, You H, Lee KA, Lee WJ. 2012. Genetic evidence of a redox-dependent systemic wound response via Hayan protease-phenoloxidase system in Drosophila. EMBO Journal 31:1253-1265. DOI: 10.1038/emboj.2011.476.

Patrnogic J, Castillo JC, Shokal U, Yadav S, Kenney E, Heryanto C, Ozakman Y, Eleftherianos I. 2018. Pre-exposure to non-pathogenic bacteria does not protect Drosophila against the entomopathogenic bacterium Photorhabdus. PLOS ONE 13:1-14. DOI: 10.1371/journal.pone.0205256.

Pham LN, Dionne MS, Shirasu-Hiza M, Schneider DS. 2007. A specific primed immune response in Drosophila is dependent on phagocytes. PLoS Pathogens 3:e26. DOI: 10.1371/journal.ppat.0030026.

Reber A, Chapuisat M. 2012. No evidence for immune priming in ants exposed to a fungal pathogen. PloS One 7:e35372. DOI: 10.1371/journal.pone.0035372.

Rimer J, Cohen IR, Friedman N. 2014. Do all creatures possess an acquired immune system of some sort? BioEssays 36:273-281. DOI: 10.1002/bies.201300124.

Rodríguez De La Vega RC, García BI, D’Ambrosio C, Diego-García E, Scaloni A, Possani LD. 2004. Antimicrobial peptide induction in the haemolymph of the Mexican scorpion Centruroides limpidus limpidus in response to septic injury. Cellular and Molecular Life Sciences 61:1507-1519. DOI: 10.1007/s00018-004-4096-x.

Roth O, Joop G, Eggert H, Hilbert J, Daniel J, Schmid-Hempel P, Kurtz J. 2010. Paternally derived immune priming for offspring in the red flour beetle, Tribolium castaneum. Journal of Animal Ecology 79:403-413. DOI: 10.1111/j.1365-2656.2009.01617.x.

Roth O, Kurtz J. 2009. Phagocytosis mediates specificity in the immune defence of an invertebrate, the woodlouse Porcellio scaber (Crustacea: Isopoda). Developmental and comparative immunology 33:1151-5. DOI: 10.1016/j.dci.2009.04.005.

Rowley AF, Powell A. 2007. Invertebrate immune systems specific, quasi-specific, or nonspecific? Journal of Immunology 179:7209-7214.

Santos-Matos G, Wybouw N, Martins NE, Zélé F, Riga M, Leitão AB, Vontas J, Grbić M, Van Leeuwen T, Magalhães S, Sucena É. 2017. Tetranychus urticae mites do not mount an induced immune response against bacteria. Proceedings of the Royal Society $B$ 284:20170401. DOI: 10.1098/rspb.2017.0401.

Santos D, Reis P, Pimenta A. 2016. Antimicrobial Peptides in Spider Venoms. In: Gopalakrishnakone P, Corzo G, de Lima M, Diego-García E eds. Spider Venoms. Dordrecht: Dordrecht, 361-377. DOI: 10.1007/978-94-007-6646-4.

Shaw DK, Wang X, Brown LJ, Chávez ASO, Reif KE, Smith AA, Scott AJ, Mcclure EE, 
408

409

410

411

412

413

414

415

416

417

418

419

420

421

422

423

424

425

426

427

428

429

430

431

432

433

434

435

436

437

438

439

440

441

442

443

Boradia VM, Hammond HL, Sundberg EJ, Snyder GA, Liu L, Deponte K, Villar M, Ueti MW, de la Fuente J, Ernst RK, Pal U, Fikrig E, Pedra JHF. 2017. Infection-derived lipids elicit an immune deficiency circuitcircuit in arthropods. Nature Communications 8:14401. DOI: $10.1038 /$ ncomms14401.

Sonenshine DE, Ceraul SM, Hynes WE, Macaluso KR, Azad AF. 2003. Expression of defensinlike peptides in tick hemolymph and midgut in response to challenge with Borrelia burgdorferi , Escherichia coli and Bacillus subtilis. Experimental and Applied Acarology 28:127-134.

Taylor D. 2006. Innate Immunity in ticks: a review. Journal of the Acarological Society of Japan 15:109-127.

Team RDC. 2019. $R$ : a language and environment for statistical computing. Vienna, Austria: $\mathrm{R}$ Foundation for Statistical Computing.

Tetreau G, Dhinaut J, Gourbal B, Moret Y. 2019. Trans-generational Immune Priming in Invertebrates: Current Knowledge and Future Prospects. Frontiers in Immunology 10:1938. DOI: 10.3389/fimmu.2019.01938.

Vargas V, Moreno-García M, Duarte-Elguea E, Lanz-Mendoza H. 2016. Limited specificity in the injury and infection priming against bacteria in Aedes aegypti mosquitoes. Frontiers in Microbiology 7:975. DOI: 10.3389/fmicb.2016.00975.

Wang X, Wang G. 2016. Insights into Antimicrobial Peptides from Spiders and Scorpions. Protein \& Peptide Letters 23:707-721. DOI: 10.2174/0929866523666160511151320.

World Spider Catalog. 2019.World Spider Catalog. Available at http://wsc.nmbe.ch. DOI: $10.24436 / 2$.

Wright S, Goodacre SL. 2012. Evidence for antimicrobial activity associated with common house spider silk. BMC Research Notes 5:326. DOI: 10.1186/1756-0500-5-326.

Wu G, Li M, Liu Y, Ding Y, Yi Y. 2015a. The specificity of immune priming in silkworm, Bombyx mori, is mediated by the phagocytic ability of granular cells. Journal of Insect Physiology 81:60-8. DOI: 10.1016/j.jinsphys.2015.07.004.

Wu G, Yi Y, Sun J, Li M, Qiu L. 2015b. No evidence for priming response in Galleria mellonella larvae exposed to toxin protein PirA2B2 from Photorhabdus luminescens TT01: An association with the inhibition of the host cellular immunity. Vaccine 33:6307-6313. DOI: 10.1016/j.vaccine.2015.09.046.

Wu G, Zhao Z, Liu C, Qiu L. 2014. Priming Galleria mellonella (Lepidoptera: Pyralidae) larvae with heat-killed bacterial cells induced an enhanced immune protection against Photorhabdus luminescens TT01 and the role of innate Immunity in the process. Journal of Economic Entomology 107:559-569. DOI: 10.1603/EC13455.

Peer) reviewing PDF | (2020:02:45936:1:0:NEW 27 Apr 2020) 
Figure 1

Kaplan-Meier survival curves of scorpions (A) and spiders (B), under different priming treatments.

After the priming period, half of the individuals of each treatment were injected with the control solution (Naive - PBS, PBS - PBS and LPS - PBS) or with the bacterial solution (Naive Bacteria, PBS - Bacteria, LPS - Bacteria). Scorpions: Naive - PBS, $n=54$; Naive - Bacteria, $n$ $=52 ;$ PBS - PBS, $n=53 ;$ PBS - Bacteria, $n=55 ;$ LPS - PBS, $n=51 ;$ LPS - Bacteria, $n=57$. Spiders: Naive - PBS, $n=55$; Naive - Bacteria, $n=48$; PBS - PBS, $n=50$; PBS - Bacteria, $n=$ 52; LPS - PBS, $n=47$; LPS - Bacteria, $n=47$. See text for statistical details.

A)

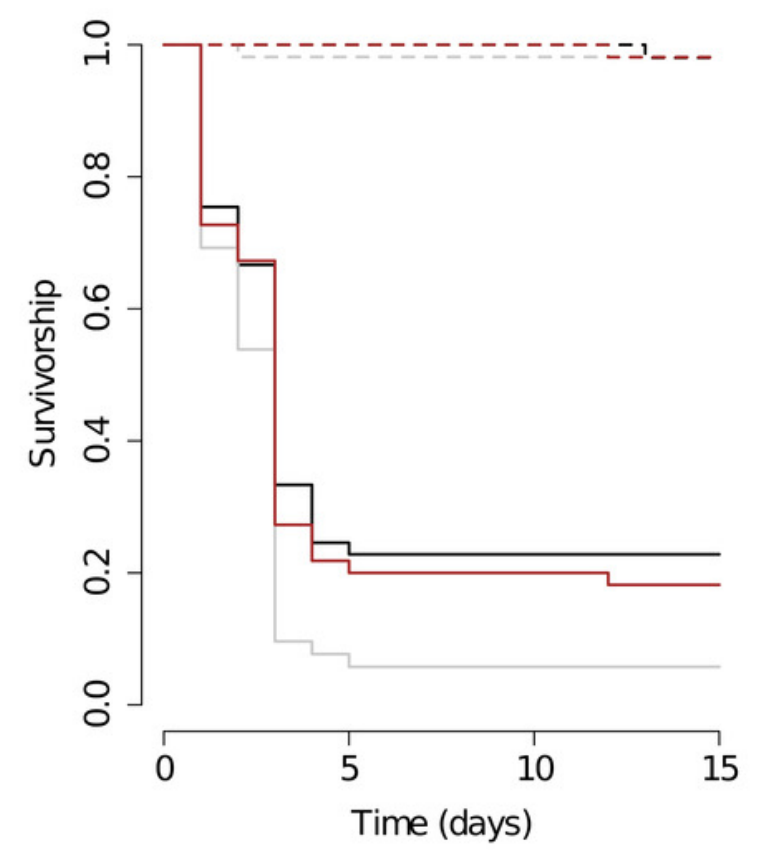

B)

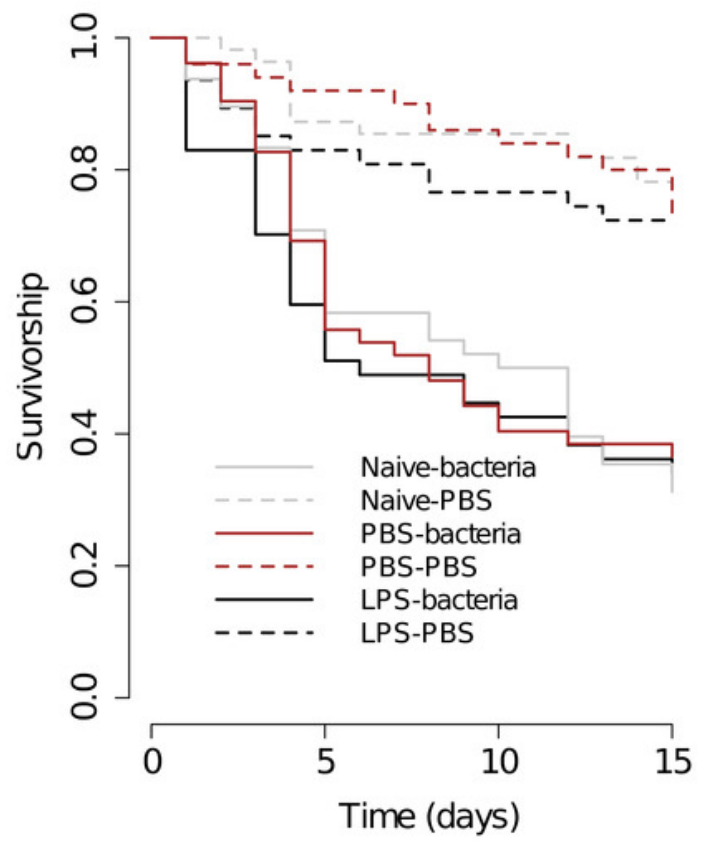


Figure 2

Growth in vitro of Escherichia coli when mixed with hemolymph samples of scorpions from the different priming treatments, measured as optical density (OD)

Stars indicate treatments that significantly reduced the bacterial growth as compared to the bacterial growth in the absence of any hemolymph (dashed line, $\mathrm{OD}_{630}=0.763$ ). Overall, treatments did not differ in their capacity to inhibit the bacterial growth. Naive: $n=9$; PBS: $n$ $=6$ and LPS: $\mathrm{n}=9$.

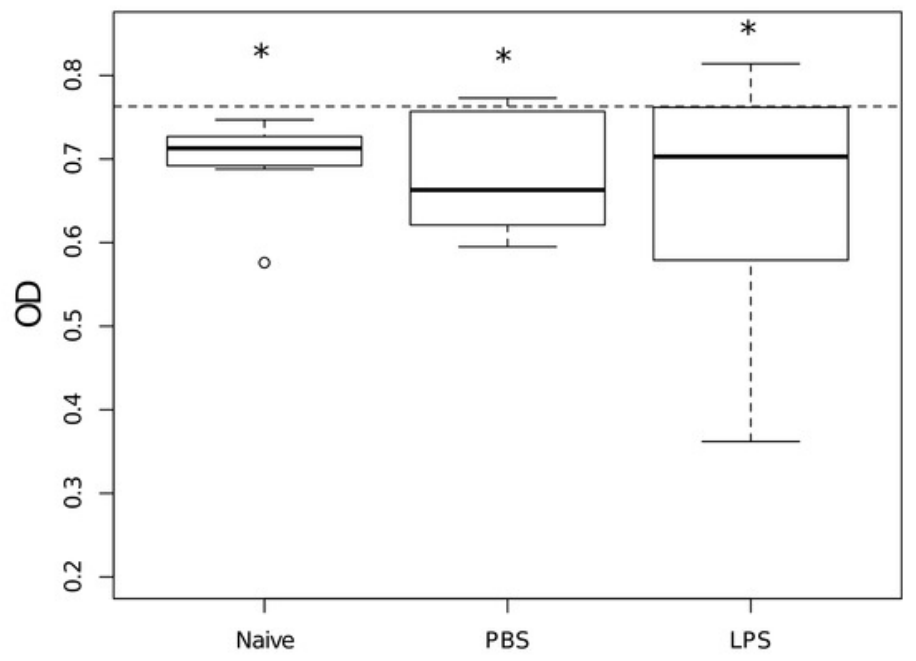




\section{Table $\mathbf{1}$ (on next page)}

Survival analysis pairwise comparisons of priming treatments exposed to a control solution (- PBS) or to a bacterial challenge (- Bacteria).

The Gehan-Breslow-Wilcoxon test compares survival rates at early time points and the Logrank tests compares them at late time points. See materials and methods for details on priming treatments. 


\begin{tabular}{|c|c|c|}
\hline Comparison & Gehan-Breslow-Wilcoxon & Log-rank \\
\hline \multicolumn{3}{|l|}{ Scorpions } \\
\hline Naive - Bacteria vs Naive - PBS & $\mathrm{z}=-7.8, \mathbf{p}<\mathbf{0 . 0 0 1}$ & $\mathrm{z}=4.1, \mathbf{p}<\mathbf{0 . 0 0 1}$ \\
\hline PBS - Bacteria vs PBS - PBS & $\mathrm{z}=-8.3, \mathbf{p}<\mathbf{0 . 0 0 1}$ & $\mathrm{z}=4.3, \mathbf{p}<\mathbf{0 . 0 0 1}$ \\
\hline LPS - Bacteria vs LPS - PBS & $\mathrm{z}=-7.8, \mathbf{p}<\mathbf{0 . 0 0 1}$ & $\mathrm{z}=4.1, \mathbf{p}<\mathbf{0 . 0 0 1}$ \\
\hline LPS - Bacteria vs Naive - Bacteria & $\mathrm{z}=1.9, \mathbf{p}=\mathbf{0 . 0 5}$ & $z=-3.65, \mathbf{p}=\mathbf{0 . 0 3}$ \\
\hline PBS - Bacteria vs Naive - Bacteria & $\mathrm{z}=1.9, \mathrm{p}=0.11$ & $z=-3.65, p=0.07$ \\
\hline PBS - Bacteria vs LPS - Bacteria & $z=0.38, p=0.69$ & $z=-0.63, p=0.53$ \\
\hline Naive - PBS vs PBS - PBS & $\mathrm{z}=0, \mathrm{p}>0.05$ & $z=0.01, p=0.99$ \\
\hline Naive - PBS vs LPS - PBS & $\mathrm{z}=-0.02, \mathrm{p}=0.98$ & $\mathrm{z}=-0.03, \mathrm{p}=0.98$ \\
\hline PBS - PBS vs LPS - PBS & $\mathrm{z}=-0.01, \mathrm{p}=0.98$ & $\mathrm{z}=-0.03, \mathrm{p}=0.98$ \\
\hline \multicolumn{3}{|l|}{ Spiders } \\
\hline Naive - Bacteria vs Naive - PBS & $z=-4.7, \mathbf{p}<\mathbf{0 . 0 0 0 1}$ & $z=-4.06, \mathbf{p}<\mathbf{0 . 0 0 0 1}$ \\
\hline PBS - Bacteria vs PBS - PBS & $z=-4.0, \mathbf{p}<\mathbf{0 . 0 0 0 1}$ & $z=-3.7, \mathbf{p}<\mathbf{0 . 0 0 1}$ \\
\hline LPS - Bacteria vs LPS - PBS & $\mathrm{z}=-3.4, \mathbf{p}<\mathbf{0 . 0 0 1}$ & $\mathrm{z}=3.4, \mathbf{p}<\mathbf{0 . 0 0 1}$ \\
\hline LPS - Bacteria vs Naive - Bacteria & $z=-0.75, p=0.44$ & $\mathrm{z}=0.27, \mathrm{p}=0.79$ \\
\hline PBS - Bacteria vs Naive - Bacteria & $z=-0.06, p=0.95$ & $\mathrm{z}=-0.12, p=0.9$ \\
\hline PBS - Bacteria vs LPS - Bacteria & $\mathrm{z}=-0.80, \mathrm{p}=0.42$ & $\mathrm{z}=0.41, \mathrm{p}=0.68$ \\
\hline Naive - PBS vs PBS - PBS & $z=0.53, p=0.59$ & $z=0.61, p=0.54$ \\
\hline Naive - PBS vs LPS - PBS & $z=-0.91, p=0.36$ & $z=-0.78, p=0.44$ \\
\hline PBS - PBS vs LPS - PBS & $z=-0.34, p=0.73$ & $z=-0.19, p=0.85$ \\
\hline
\end{tabular}

